\title{
CARBON DIOXIDE OUTPUT IN ANAESTHESIA
}

\author{
J.A. BAIN AND W.E. SPOEREL $†$
}

FOR THE PAST FOUR YEARS we have used a modified Mapleson D type breathing circuit $^{1}$ (Figure 1) routinely to the virtual exclusion of the circle breathing system as well as other breathing systems recommended for paediatric anaesthesia. Our recommendation of a fresh gas inflow of $70 \mathrm{ml} / \mathrm{kg}$ body weight ${ }^{2}$ was found to be satisfactory in adult patients; we also recommended not to reduce the fresh gas inflow below $3.5 \mathrm{l} / \mathrm{min}$, partly because of higher rates of $\mathrm{CO}_{2}$ output in children, and partly because commonly used vaporizers do not provide the indicated concentrations at lower flows.

It could be shown that the patient's arterial $\mathrm{CO}_{2}$ level could be manipulated with this breathing system independent of pulmonary ventilation as long as the

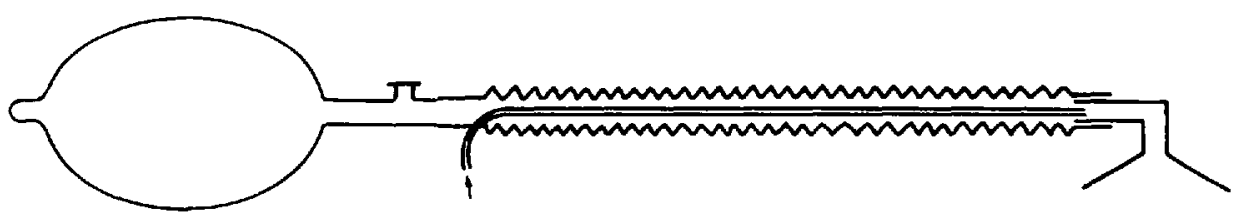

Figure 1. Modified Mapleson D circuit ${ }^{1} \uparrow$ fresh gas inflow.

minute volume on the ventilator was well in excess of the volume of fresh gas entering the system. ${ }^{3-5} \mathrm{~A}$ curve was constructed showing that the arterial $\mathrm{P}_{\mathrm{CO}_{2}}$ will change predictably with an increase or decrease in fresh gas flow (Figure 2). This curve was based on patients whose $\mathrm{CO}_{2}$ output was assumed to be within a normal range; if the patient's $\mathrm{CO}_{2}$ production was increased, as it would be in the case of elevated body temperature, a higher fresh gas inflow would be required for the elimination of $\mathrm{CO}_{2}$ to maintain a normal arterial $\mathrm{P}_{\mathrm{CO}_{2}}$

In order to elucidate the mode of $\mathrm{CO}_{2}$ elimination in the circuit, $\mathrm{CO}_{2}$ was measured at various intervals along the breathing tube, using a mass spectrometer (Elmer-Perkins) in patients breathing spontaneously and on controlled ventilation. In the tracheal tube, the $\mathrm{CO}_{2}$ concentration fluctuated between the alveolar $\mathrm{CO}_{2}$ concentration at the end of expiration and a low value at the end of inspiration, depending on fresh gas inflow and the amount of rebreathing (Figure 3 ). However, proximal to the point of fresh gas inflow, these fluctuations between inspiratory and expiratory $\mathrm{CO}_{2}$ concentration were markedly diminished and a nearly constant $\mathrm{CO}_{2}$ level was observed at the end of the breathing tube near the reservoir bag throughout the respiratory phases.

'Presented at the Annual Meeting of the Canadian Anaesthetists' Society, Kingston, Ontario, June 23-26, 1975.

$\uparrow$ Department of Anaesthesia, University of Western Ontario, Victoria Hospital and University Hospital, London, Canada. 


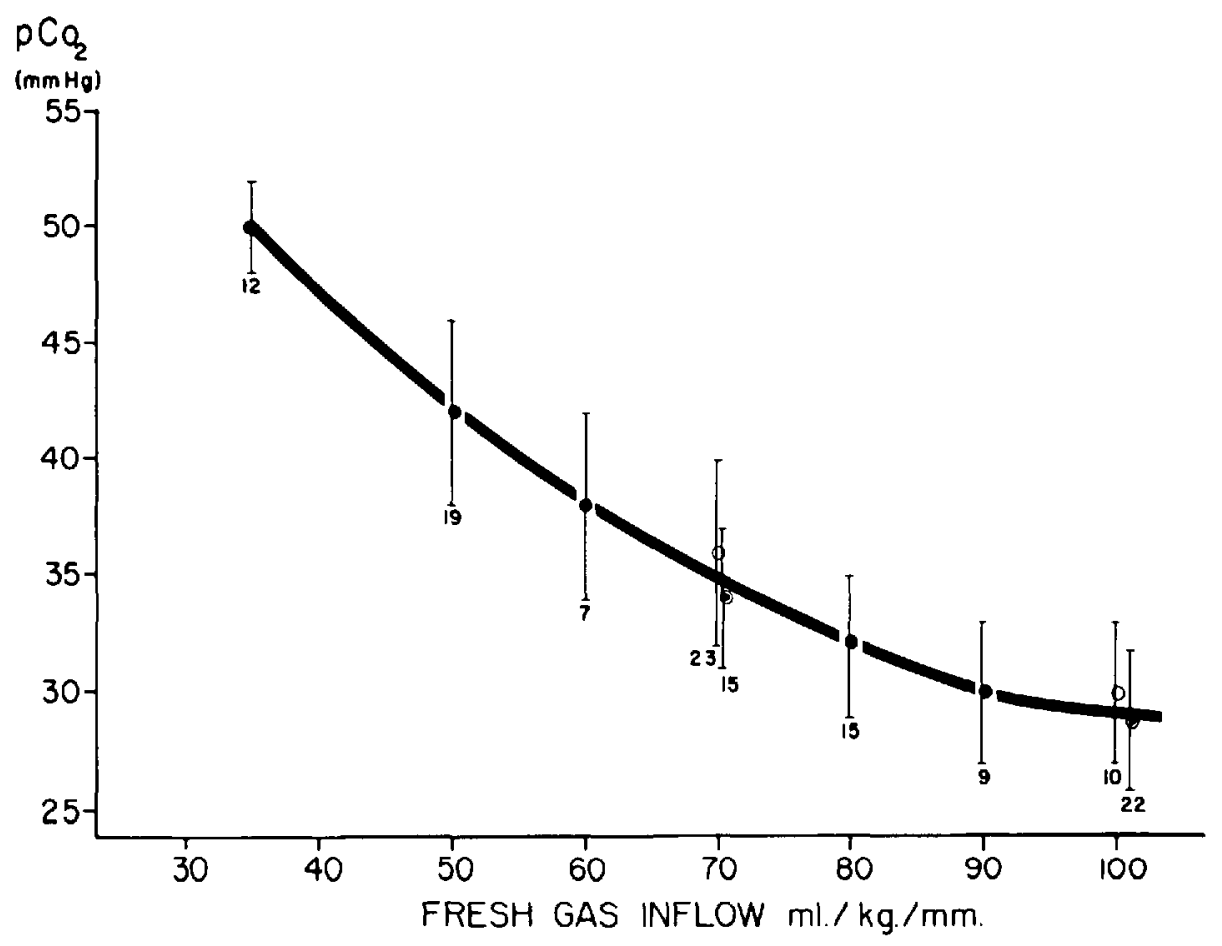

Ficure 2. Relationship between Paro.: and fresh gas inflow during controlled ventilation. ${ }^{3}$ $I=$ standard deviation.

In anaesthesia with nitrous oxide and oxygen supplemented with potent anaesthetic vapours, a significant volume of gas is taken up only during the first 15 minutes of anaesthesia. ${ }^{6}$ Thereafter the uptake of $\mathrm{N}_{2} \mathrm{O}$ is only minimal and it can be assumed that the volume of fresh gas inflow is nearly equal to the volume of gas outflow from the expiratory valve throughout the maintenance period of anaesthesia, providing that the same fresh gas composition is maintained and the fresh gas inflow is constant and sufficient to maintain a near normal arterial $\mathrm{CO}_{2}$ tension. Since the $\mathrm{CO}_{2}$ concentration in the gas emerging from the expiratory valve is nearly constant throughout the respiratory cycle, and the fresh gas inflow is set on the gas machine, the patient's $\mathrm{CO}_{2}$ output at any given moment can be estimated by determining the $\mathrm{CO}_{2}$ concentration in volume per cent with a $\mathrm{CO}_{2}$ analyzer and multiplying this value by the volume of fresh gas inflow per minute. We have used instruments by Beckman and by Hartmann and Braun (Germany) to obtain the data to be reported here, but instruments or methods with much slower response time would be adequate.

If the gas flow is kept constant throughout the course of anaesthesia, and the patient is on controlled ventilation with a constant rate and volume, then changes in the $\mathrm{CO}_{2}$ output measured by this technique should be a reflection of the patient's $\mathrm{CO}_{2}$ production and the technique would allow a continuous monitoring of the patient's metabolic activity. In spontaneously breathing patients, changes in the patient's respiratory volume would induce transient fluctuation; however, obser- 


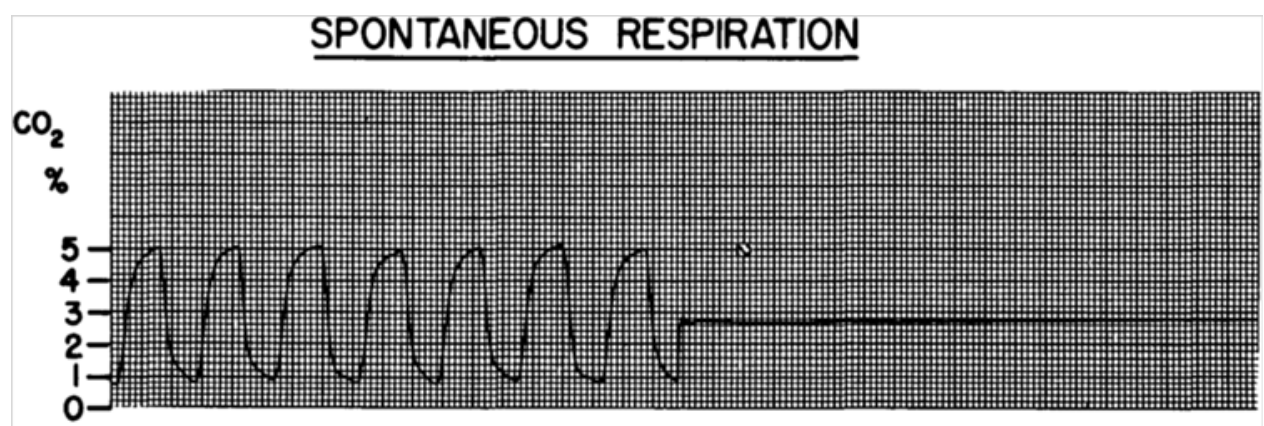

TRACHEA

END OF BAIN TUBE

\section{CONTROLLED VENTILATION}

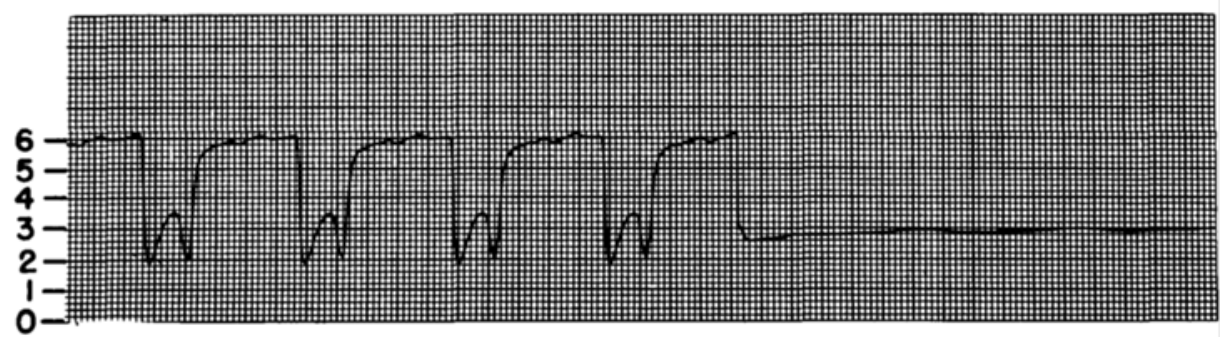

TRACHEA

END OF BAIN TUBE

Ficure 3. $\mathrm{CO}_{2}$ levels ( $\mathrm{vol} \%$ ) during spontaneous and controlled ventilation measured inside the trachea and at the end of the breathing tube (Bain tube) near the reservoir bag or the bellows of the ventilator.

vation over prolonged periods would still make it possible to employ this measurement as a useful indicator. Modern flowmeters on anaesthetic gas machines provide a nearly constant flow and the $\mathrm{CO}_{2}$ analyzers employed can be read accurately to 0.1 volume per cent. Thus changes in the $\mathrm{CO}_{2}$ output of the magnitude of 5 $\mathrm{ml} / \mathrm{min}$ should be readily detectable.

\section{Method of Study and Results}

\section{(a) Spontaneous Breathing}

In order to test this hypothesis, we compared two anaesthetic techniques in a uniform group of out-patients undergoing anaesthesia for the removal of impacted molars. All were healthy patients between 19 and 30 years of age and their weight was normal. No pre-medication was given and all were induced with a sleeping dose of thiopentone, intubated nasotracheally after a single dose of succinylcholine and allowed to breathe spontaneously a mixture of $\mathrm{N}_{2} \mathrm{O}$ and $\mathrm{O}_{2}$ at a ratio of 5:2 at a flow rate of about $70 \mathrm{ml} / \mathrm{kg}$. The flow rate was accurately set and not changed during the procedure. One group ( 24 patients - 11 male, 13 female) was given alphaprodine (Nisentil) in increments of $6 \mathrm{mg}$ as required and the dosage was 


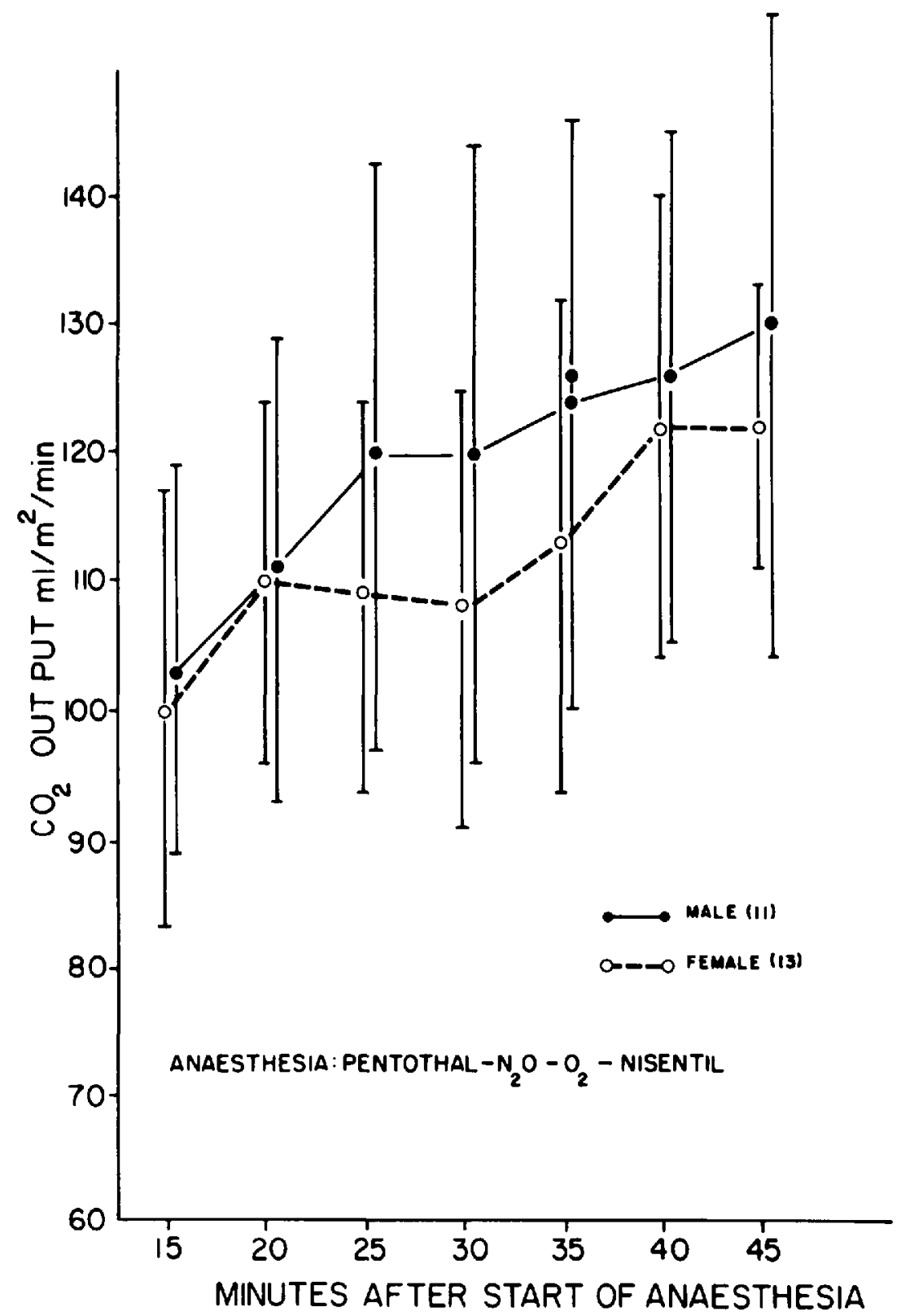

Figure 4. Dental anaesthesia: $\mathrm{CO}_{2}$ output in 24 patients breathing spontaneously through nasotracheal tube. Maintenance with $\mathrm{N}_{2} \mathrm{O}-\mathrm{O}_{2}(70 \mathrm{ml} / \mathrm{kg})$ and alphaprodine.

$I=$ standard deviation.

gauged to maintain a respiratory rate of about $12 /$ minute. The other group ( 25 patients -8 male, 17 female) received 1 per cent halothane from a Fluotec Mark III vaporizer throughout the course of the anaesthetic. Carbon dioxide was measured with a Uras $\mathrm{CO}_{2}$ analyzer (Hartmann and Braun), sampling near the expiratory valve. The $\mathrm{CO}_{2}$ output was expressed in $\mathrm{ml} / \mathrm{m}^{2} / \mathrm{min}$, the surface area being 


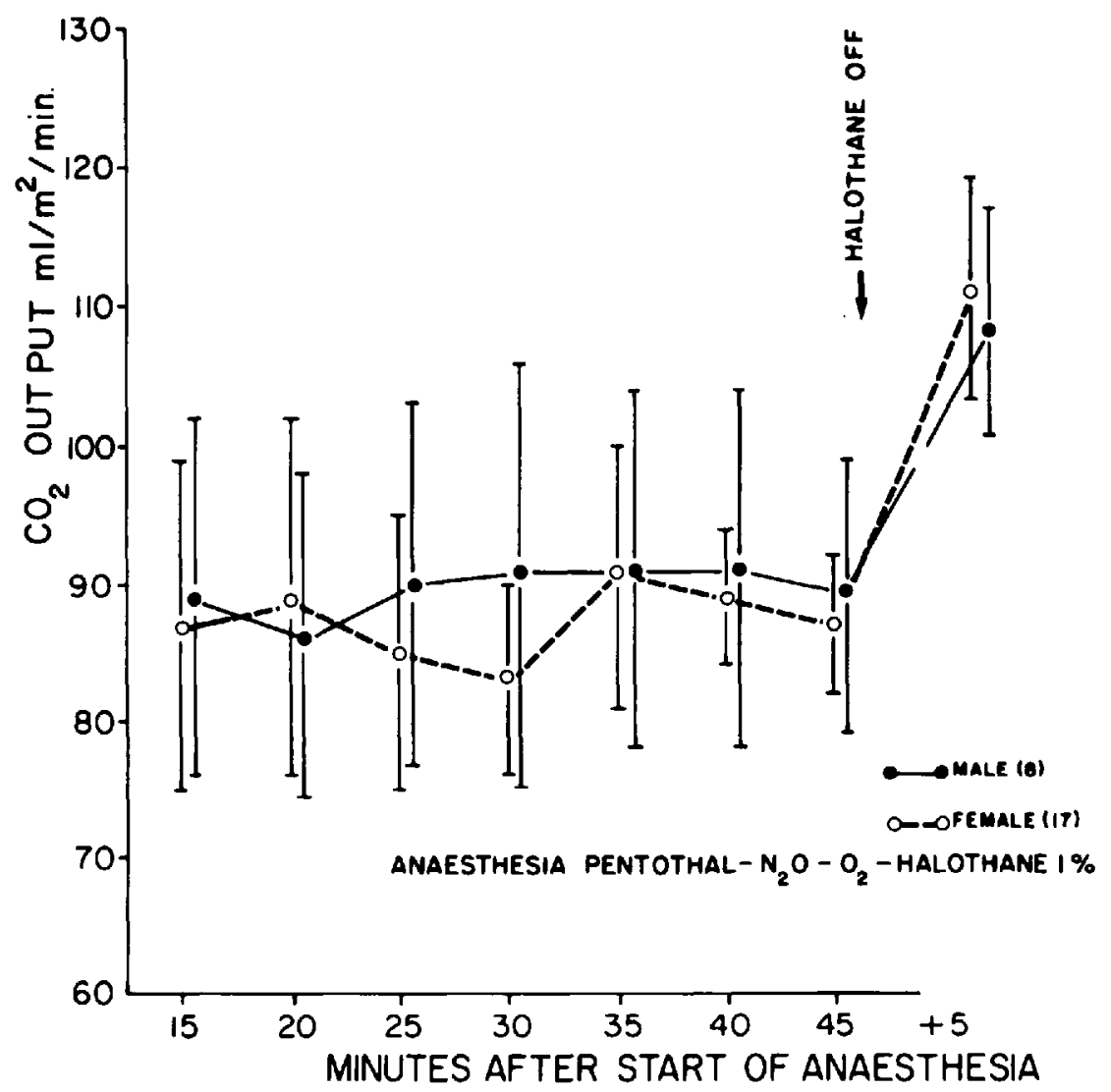

Frgure 5. Dental anaesthesia: $\mathrm{CO}_{9}$ output in 25 patients breathing spontaneously through nasotracheal tube. Maintenance with $\mathrm{N}_{2} \mathrm{O}-\mathrm{O}_{2}(70 \mathrm{ml} / \mathrm{kg}$ inflow $)$ and halothane 1 per cent.

$I=$ standard deviation.

determined from weight and height tables. In addition, the $\mathrm{Pa}_{\mathrm{C}^{\circ} \mathrm{O}}$ was determined about 40 minutes after the induction of anaesthesia, prior to the end of surgery.

The results show a marked difference between the two groups, (Figure 4): in light anaesthesia with $\mathrm{N}_{2} \mathrm{O}$ and alphaprodine, the $\mathrm{CO}_{2}$ output increased from an initial low level of about $100 \mathrm{ml} / \mathrm{m}^{2} /$ min at 15 minutes after induction to a mean high of about $130 \mathrm{ml} / \mathrm{m}^{2} / \mathrm{min}$. The incremental doses of the narcotic tended to produce a transient plateau in most patients. There were considerable differences between individual patients, as indicated by the large standard deviations. In spite of the light level of anaesthesia and a low total dose of alphaprodine (mean dosage $24 \mathrm{mg}$ in females and $30 \mathrm{mg}$ in males) there was respiratory depression indicated by a mean $\mathrm{Pa}_{\mathrm{CO}_{2}}$ of $44 \pm 4$ torr in this group.

The halothane cases (Figure 5) showed a fairly constant $\mathrm{CO}_{2}$ output throughout the procedure at a lower level of about $90 \mathrm{ml} / \mathrm{m}^{2} / \mathrm{min}$ and the individual differences were less. When halothane was turned off without any other changes and without disturbing the patient, a significant rise in $\mathrm{CO}_{2}$ output was noted within five minutes in all cases. The $\mathrm{Pa}_{1}{ }^{\circ} \mathrm{O}_{2}$ in this group was $37 \pm 2$ torr. 
TABLE I

$\mathrm{CO}_{2}$ Output-Controlled Ventilation

\begin{tabular}{|c|c|c|c|c|c|c|}
\hline \multicolumn{7}{|c|}{ Values one hour after induction } \\
\hline Main agent & $\begin{array}{c}\text { No. of } \\
\text { pat. }\end{array}$ & $\begin{array}{c}\text { Age } \\
\text { (mean) }\end{array}$ & Range & $\begin{array}{c}\text { Surface } \\
\text { area }\left(\mathrm{m}^{2}\right) \\
(\text { mean })\end{array}$ & $\begin{array}{c}\text { Body temp. } \\
\left({ }^{\circ} \mathrm{C}\right) \\
\text { (mean } \pm \text { S.D.) }\end{array}$ & $\begin{array}{c}\mathrm{CO}_{2} \text { output } \\
\left(\mathrm{ml} / \mathrm{m}^{2} / \mathrm{min}\right) \\
(\text { mean } \pm \text { S.D.) }\end{array}$ \\
\hline $\begin{array}{l}\text { Halothane } \\
\text { Ethrane } \\
\text { Nisentil }\end{array}$ & $\begin{array}{l}11 \\
14 \\
17\end{array}$ & $\begin{array}{l}55 \\
53 \\
53\end{array}$ & $\begin{array}{l}(40-74) \\
(21-74) \\
(22-75)\end{array}$ & $\begin{array}{l}1.92 \\
1.87 \\
1.72\end{array}$ & $\begin{array}{l}35.7 \pm 0.7 \\
36.2 \pm 0.7 \\
35.8 \pm 0.7\end{array}$ & $\begin{array}{l}87 \pm 11 \\
98 \pm 19 \\
93 \pm 13\end{array}$ \\
\hline
\end{tabular}

\section{(b) Controlled Ventilation}

In patients on controlled ventilation, the $\mathrm{CO}_{2}$ output was determined by the same technique. Forty-two patients of normal body build and in category 1 or 2 of the ASA Classification, undergoing major surgical procedures were induced with thiopentone and ventilated with an Air Shields ventilator-ventimeter with a tidal volume of $10 \mathrm{ml} / \mathrm{kg}$ body weight. The fresh gas inflow of $\mathrm{N}_{2} \mathrm{O}$ and $\mathrm{O}_{2}$, at a ratio of $5: 2$, was about $70 \mathrm{ml} / \mathrm{kg} / \mathrm{min}$. Anaesthesia was maintained with halothane 0.7 per cent to 1 per cent, ethrane 1 per cent to 1.5 per cent or intermittent doses of alphaprodine (Table I). Tubarine or pancuronium were used as muscle relaxants. The rectal or oesophageal temperature was monitored. Carbon dioxide was sampled from the breathing tube near the ventilator and measured with a Beckman $\mathrm{CO}_{2}$ analyzer; only the values obtained one hour after induction are reported here. As in the spontaneously breathing patients there were considerable individual variations, but the mean values were of the same order. The $\mathrm{CO}_{2}$ output values for halothane (mean $87 \pm 11 \mathrm{ml} / \mathrm{m}^{2} / \mathrm{min}$ ) were lower than for ethrane $(98 \pm 19)$, although this difference was not statistically significant. We had expected higher values in the narcotic group (mean $92 \pm 13$ ) in accordance with the observations in spontaneously breathing patients. However, the dosage of alphaprodine was higher in this group and all patients were pre-medicated with narcotics and paralyzed with muscle relaxants.

Since the $\mathrm{CO}_{2}$ output was not significantly different between the three groups, is seemed reasonable to calculate a mean $\mathrm{CO}_{2}$ output of $93 \pm 14 \mathrm{ml} / \mathrm{m}^{2} / \mathrm{min}$ for the 42 patients.

This was in contrast to six obese patients (three males, three females) with a mean weight of $110 \mathrm{~kg}$ and a mean surface area of $2.15 \mathrm{~m}^{2}$. Their mean $\mathrm{CO}_{2}$ output of $114 \pm 17 \mathrm{ml} / \mathrm{m}^{2} / \mathrm{kg}$ (Table II) was significantly higher than that of patients in a normal weight range. One might expect a lower value considering the lower metabolic rate of fat tissue and further studies are required to verify this observation. However, when the $\mathrm{CO}_{2}$ output was related to body weight there was no difference.

After observing unexpectedly high values in a patient who underwent operation while on hyperalimentation, we have measured the $\mathrm{CO}_{2}$ output in eight patients on hyperalimentation under anaesthesia and all showed a marked elevation (Table II). Their mean $\mathrm{CO}_{2}$ output was $160 \pm 25 \mathrm{ml} / \mathrm{m}^{2} / \mathrm{min}$, significantly higher than the value of $93 \pm 14 \mathrm{ml} / \mathrm{m}^{2} / \mathrm{min}$ in our group of normal patients, representing 


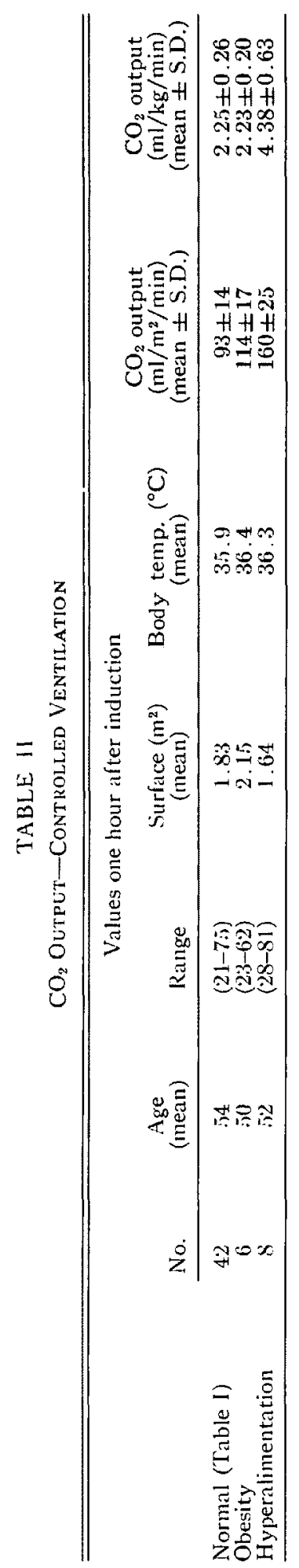


possibly a 72 per cent increase in metabolism. Related to body weight, the $\mathrm{CO}_{2}$ output was almost double ( 92 per cent when compared to normal patients). The higher metabolic rate in these patients has been attributed to the free amino-acids contained in the hyperalimentation solution. ${ }^{7}$

\section{Discussion}

Carbon dioxide elimination in a partial rebreathing system depends on $\mathrm{CO}_{2}$ production and fresh gas inflow. The application of standards for the prediction of a required fresh gas inflow is only valid in patients in a normal metabolic state. For the safe use of partial rebreathing circuits an estimate of the patient's $\mathrm{CO}_{2}$ production is helpful to avoid $\mathrm{CO}_{2}$ accumulation and respiratory acidosis in unrecognized states of increased metabolic activity.

The values for $\mathrm{CO}_{2}$ output obtained by this technique are of the same order as those reported by other investigators. ${ }^{8.9}$ The technique measures only the actual $\mathrm{CO}_{2}$ output and this would reflect $\mathrm{CO}_{2}$ production if the patient is in a steady state. Changes in ventilation and in fresh gas inflow will alter the steady state. Our anaesthetic technique with flow rates near the alveolar ventilation represents an almost isocapnic ventilation and marked fluctuations in the patient's $\mathrm{CO}_{2}$ levels are avoided. We think the technique of estimating $\mathrm{CO}_{2}$ output is valid 15 minutes after the change of the patient's atmosphere from room air to a $\mathrm{N}_{2} \mathrm{O}-\mathrm{O}_{2}$ mixture at induction of anaesthesia; at that time the alveolar $\mathrm{N}_{2} \mathrm{O}$ concentration should be above 90 per cent of the inspired concentration and the period of a significant uptake of the $\mathrm{N}_{2} \mathrm{O}$ has passed. ${ }^{6}$

Our findings indicate that the degree of anaesthetic depression represents a factor in the relationship between fresh gas inflow and the $\mathrm{Pa}_{\mathrm{CO}_{2}}$. A significantly higher $\mathrm{CO}_{2}$ output was seen in spontaneously breathing patients under light nitrous oxide-narcotic anaesthesia when compared to patients under halothane anaesthesia. In our small series of patients on hyperalimentation a markedly elevated $\mathrm{CO}_{2}$ output was found. This must be taken into account when such patients are anaesthetized using a partial rebreathing system and fresh gas inflows of 120 $\mathrm{ml} / \mathrm{kg} / \mathrm{min}$ are recommended or actual monitoring of the $\mathrm{CO}_{2}$ output as described. For obese patients the $\mathrm{CO}_{2}$ output per square meter is higher than in patients within a normal weight range; however, their $\mathrm{CO}_{2}$ output was of the same order as in normal patients when related to body mass. It would seem advisable to calculate the flow rates required for obese patients on the basis of their body weight.

The breathing circuit ${ }^{1}$ now in general use in our hospitals makes it possible to determine the patient's $\mathrm{CO}_{2}$ output instantaneously and continuously by the technique described. It allows the continuous monitoring of the $\mathrm{CO}_{2}$ output with sufficient accuracy to be clinically useful and to detect otherwise unrecognizable states of increased metabolic activity.

\section{SUMMary}

In a Mapleson D circuit the carbon dioxide content of gases, sampled at the breathing bag or near the bellows of the ventilator, is virtually constant throughout 
the phases of respiration. Assuming that after induction of anaesthesia the fresh gas inflow, if kept constant, is essentially equal in volume to the gas vented at the expiratory valve, $\mathrm{CO}_{2}$ output can be calculated by multiplying the fresh gas inflow by the $\mathrm{CO}_{2}$ content of the vented gas measured with a suitable $\mathrm{CO}_{2}$ analyzer.

Anaesthesia with nitrous oxide-oxygen, supplemented with low doses of alphaprodine or halothane was compared in two groups of young patients who underwent dental surgery and who were breathing spontaneously. While the $\mathrm{CO}_{2}$ output in the group supplemented with alphaprodine increased from about 100 to 130 $\mathrm{ml} / \mathrm{m}^{2} / \mathrm{min}$, the halothane group showed a constant $\mathrm{CO}_{2}$ output of about 90 $\mathrm{ml} / \mathrm{m}^{2} / \mathrm{min}$ followed by a significant rise within 5 minutes after halothane was discontinued.

In 42 patients on controlled ventilation, no significant difference was found in the $\mathrm{CO}_{2}$ output estimated one hour after induction of anaesthesia in nitrous oxideoxygen anaesthesia supplemented by halothane, ethrane or alphaprodine.

The values obtained were $87 \pm 11 \mathrm{ml} / \mathrm{m}^{2} / \mathrm{min}$ for halothane ( 11 patients), 98 $\pm 19 \mathrm{ml} / \mathrm{m}^{2} / \mathrm{min}$ for ethrane (14) and $93 \pm 13 \mathrm{ml} / \mathrm{m}^{2} / \mathrm{min}$ for the narcotic supplemented anaesthesia (17). The mean $\mathrm{CO}_{2}$ output for all 42 patients was $93 \pm 14$ $\mathrm{ml} / \mathrm{m}^{2} / \mathrm{min}$.

Six markedly obese patients under the same anaesthetic technique had a $\mathrm{CO}_{2}$ output of $114 \pm 17 \mathrm{ml} / \mathrm{m}^{2} / \mathrm{min}$; however, their $\mathrm{CO}_{2}$ output was similar to normal patients when calculated on the basis of body weight. A marked increase in $\mathrm{CO}_{2}$ output to a mean of $160 \pm 25 \mathrm{ml} / \mathrm{m}^{2} /$ min was found in eight patients undergoing operation while on hyperalimentation.

The technique described appears suitable to monitor $\mathrm{CO}_{2}$ output under anaesthesia. In order to avoid hypercarbia when using a partial rebreathing system, the fresh gas inflow must be increased above recommended values in cases with increased metabolic activity (e.g. patients receiving hyperalimentation). In obese patients the fresh gas inflow should be calculated on the basis of body weight.

\section{RÉSUMÉ}

Avec le circuit de Mapleson D, le contenu en gaz carbonique mesuré dans le ballon ou à la sortie des soufflets du respirateur est constant en pratique pendant toutes les phases de la ventilation. En admettant, qu'après l'induction de l'anesthésie le débit de gaz frais, s'il est maintenu constant, est nécessairement égal au volume de gaz s'échappant par la valve expiratoire, la production de $\mathrm{CO}_{2}$ peut être calculée en multipliant le débit de gaz frais par le contenu en $\mathrm{CO}_{2}$ de gaz s'échappant par la valve à l'aide d'un analyseur de $\mathrm{CO}_{2}$.

En ventilation spontanée, l'anesthésie par le mélange oxygène-protoxyde d'azote complété par de faibles doses d'alphaprodine ou d'halothane fut comparée chez deux groupes de patients jeunes au cours d'une chirurgie dentaire. Tandis que la production de $\mathrm{CO}_{2}$ du groupe endormi avec un complément d'alphaprodine passait de 100 à $130 \mathrm{ml} / \mathrm{m}^{2} / \mathrm{min}$, celle du groupe sous fluothane restait constante aux alentours de $90 \mathrm{ml} / \mathrm{m}^{2} / \mathrm{min}$ et montrait ensuite une augmentation significative durant less cinq minutes suivant l'arrêt du fluothane.

Les valeurs obtenues furent $87 \pm 11 \mathrm{ml} / \mathrm{m}^{2} / \mathrm{min}$ pour l'halothane (11 patients), 
$98 \pm 19 \mathrm{ml} / \mathrm{m}^{2} / \mathrm{min}$ pour l'éthrane ( 14 patients) et $93 \pm 13 \mathrm{ml} / \mathrm{m}^{2} / \mathrm{min}$ pour le narcotique (17). La production moyenne de $\mathrm{CO}_{2}$ pour les 42 patients fut $93 \pm 14$ $\mathrm{ml} / \mathrm{m}^{2} / \mathrm{min}$.

Six patients nettement obèses eurent une production de $\mathrm{CO}_{2}$ de $114 \pm 13$ $\mathrm{ml} / \mathrm{m}^{2} / \mathrm{min}$ avec la même technique anesthésique. Cependant, leur production de $\mathrm{CO}_{2}$ fut comparable à celle des patients normaux quand elle fut rapportée au poids. Une augmentation marquée de la production de $\mathrm{CO}_{2}$ à une moyenne de $160 \pm 25 \mathrm{ml} / \mathrm{m}^{2} / \mathrm{min}$ fut trouvée chez huit patients qui étaient opérés pendant une hyperalimentation.

La technique décrite apparaît utilisable pour le monitoring de la production du $\mathrm{CO}_{2}$ pendant l'anesthésie. Afin d'éviter une hypercapnie quand on utilise un système avec rebreathing partiel, le débit de gaz frais doit être augmenté au-dessus des valeurs recommandées pour les patients ayant une élévation du métabolisme (patients recevant une hyperalimentation). Chez les patients obèses le débit des gaz frais doit être calculé en se référant au poids.

\section{REFERENCES}

1. Bain, J.A. \& Spoerel, W.E. A streamlined anaesthetic system. Can. Anaes. Soc. J. 19: 426 (1972).

2. Bain, J.A. \& Spoenes, W.E. Flow requirements for a modified Mapleson D system during controlled ventilation. Can. Anaes. Soc. J. 20:629 (1973).

3. Bain, J.A. \& Spoerel, W.E. Prediction of arterial carbon dioxide tension during controlled ventilation with a modified Mapleson D system. Can. Anaes. Soc. J. 22: 34 (1975).

4. Baraka, A. Pco.. control by fresh gas flow during controlled ventilation with a semi-open circuit. Brit. J. Anaes. 41:527 (1969).

5. Henville, J.D. \& ADAis, A.P. Assessment of the Bain Anaesthetic System during controlled ventilation. Brit. J. Anaes. 47: 1024 (1975).

6. Eger, E.I. Anaesthetic uptake and action, Ch. 4. The Williams and Wilkins Co., Baltimore (1974).

7. GusberG, R.J., GuMr, F.E., \& KinNey, J.M. The demands of hyperalimentation on splanchnic blood flow and oxygen consumption. Surgical Forum 25: 56 (1974).

8. Nunn, J.F. \& Matruews, R.L. Gaseous exchange during halothane anaesthesia. Brit. J. Anaes. 31:330 (1959).

9. Nuns, J.F. Applied respiratory physiology, Ch. 6. Butterworth, London (1969). 